\title{
PEMBATASAN JUMLAH PEMBUATAN AKTA NOTARIS OLEH DEWAN KEHORMATAN PUSAT IKATAN NOTARIS INDONESIA
}

\author{
Heni Kartikosari, Rusdianto Sesung \\ Magister Kenotariatan, Fakultas Hukum Universitas Narotama Surabaya \\ Jl. Arief Rahman Hakim 51 Surabaya \\ Email : heni.kartikosari2017@gmail.com; rusdianto@narotama.ac.id
}

\begin{abstract}
To protect the Notary Public Offices and the people who use Notary services related to the legal certainty of the deed made by the Notary, the Central Board of Trustees of the Indonesian Notaries Association issued the Regulation of the Central Board of Honor No. 1 of 2017 on the Fairness Limit of Number of Permanent Deeds. The regulation is determined by the Central Board of Trustees that the limit of fairness in the deed per day is 20 (twenty) deeds. In the fact, there are so many notaries that broke the regulation. So, it must be cleared by a juridical research against that phenomenon. The research method used is normative legal research, that is legal research conducted by examining library materials or secondary law material while in searching and collecting data is done by two approaches, that is law approach and conceptual approach.
\end{abstract}

\section{Keywords: Rules of the Central Honorary Council, Notary, Deeds}

\begin{abstract}
Abstrak
Untuk melindungi Jabatan Notaris dan mayarakat yang menggunakan jasa Notaris terkait kepastian hukum dari akta yang dibuat oleh Notaris, Dewan Kehormatan Pusat Ikatan Notaris Indonesia mengeluarkan Peraturan Dewan Kehormatan Pusat Nomor 1 Tahun 2017 Tentang Batas Kewajaran Jumlah Pembuatan Akta Perhari. Dalam peraturan tersebut ditentukan oleh Dewan Kehormatan Pusat bahwa batas kewajaran dalam pembuatan akta per hari adalah sebanyak 20 (dua puluh) akta. Faktanya, di lapangan banyak ditemukan notaris yang melanggar ketentuan Dewan Kehormatan Pusat Ikatan Notaris Indonesia dengan membuat lebih dari 20 akta. Sehingga perlu dilakukan sebuah kajian yuridis untuk mengatasi fenomena tersebut. Metode penelitian yang digunakan dalam penelitian ini adalah penelitian hukum normatif, yaitu penelitian hukum yang dilakukan dengan cara meneliti bahan pustaka atau bahan hukum sekunder sedangkan dalam mencari dan mengumpulkan data dilakukan dengan dua pendekatan, yaitu pendekatan undang-undang dan pendekatan konseptual.
\end{abstract}

\section{Kata Kunci : Peraturan Dewan Kehormatan Pusat, Notaris, Akta}

\section{A. PENDAHULUAN}

Notaris oleh undang-undang diberi wewenang untuk menuangkan semua perbuatan, perjanjian dan penetapan yang dikehendaki oleh pihak atau pihak-pihak yang sengaja datang kehadapan Notaris untuk mengkonstatir keterangan itu dalam suatu akta otentik, dan agar akta yang dibuatnya itu memiliki kekuatan bukti yang lengkap dan memiliki keabsahannya. Hal tersebut ditegaskand dalam Pasal 1 angka 1 Undang-undang Nomor 30 Tahun 2004 tentang 
Jabatan Notaris sebagaimana telah diubah dengan Undang-undang Nomor 2 Tahun 2014 tentang Perubahan Atas Undang-Undang Nomor 30 Tahun 2004 tentang Jabatan Notaris (selanjutnya ditulis UUJN), yang menyatakan bahwa, "Notaris adalah pejabat umum yang berwenang untuk membuat akta otentik dan memiliki kewenangan lainnya sebagaimana dimaksud dalam undang-undang ini atau berdasarkan undang-undang lainnya".

Dalam menjalankan tugas jabatannya, Notaris wajib memenuhi semua ketentuanketentuan Jabatan Notaris dan peraturan-peraturan lainnya. Notaris bukan juru tulis sematamata, namun Notaris perlu mengkaji apakah yang diinginkan penghadap untuk dinyatakan dalam akta otentik tidak bertentangan dengan UUJN, dan aturan hukum yang berlaku. Kewajiban untuk mengetahui dan memahami syarat-syarat otentisitas, keabsahan dan sebabsebab kebatalan suatu akta Notaris, sangat penting untuk menghindari secara preventif adanya cacat hukum akta Notaris yang dapat mengakibatkan hilangnya otentisitas dan batalnya akta Notaris, yang dapat merugikan kepentingan masyarakat, terutama pihak-pihak yang berkepentingan. ${ }^{1}$

Secara normatif, peran Notaris hanyalah media untuk lahirnya suatu akta otentik Notaris bukan pihak dalam akta yang dibuatnya, sehingga hak dan kewajiban hukum yang dilahirkan dari perbuatan hukum yang disebut dalam akta Notaris, hanya mengikat pihak-pihak dalam akta itu, dan jika terjadi sengketa mengenai isi perjanjian, maka Notaris tidak terlibat dalam pelaksanaan kewajiban dan dalam menuntut suatu hak, karena Notaris berada di luar perbuatan hukum pihak-pihak tersebut.

Tugas jabatan yang dijalankan oleh para Notaris bukan sekedar pekerjaan yang diamanatkan oleh undang-undang semata, namun sekaligus menjalankan suatu fungsi sosial yang sangat penting yaitu bertanggung jawab untuk melaksanakan kepercayaan yang diberikan masyarakat umum yang dilayaninya, seorang Notaris harus berpegang teguh kepada Kode Etik Notaris.

Salah satu yang telah disepakati di dalam Kongres Ikatan Notaris Indonesia adalah mengenai batas kewajaran pembuatan akta. Hal ini tercantum di dalam Pasal 4 angka 16 Perubahan Kode Etik Notaris Tahun 2015, yang menentukan "Notaris maupun orang lain (selama yang bersangkutan menjalankan jabatan Notaris) dilarang membuat akta melebihi batas kewajaran yang batas jumlahnya ditentukan oleh Dewan Kehormatan" Dengan ditetapkannya ketentuan tersebut, maka sangat jelas bahwa batasan kewajaran pembuatan akta adalah merupakan norma yang masuk dalam Kode Etik Notaris, yang wajib dipatuhi oleh semua notaris atau semua orang yang menjalankan jabatan Notaris.

Banyak notaris dalam praktiknya yang membuat akta lebih dari 20 (dua puluh) dalam satu harinya. Akhir-akhir ini banyak dijumpai adanya Notaris yang membuat akta dengan jumlah di luar kewajaran, bahkan pada saat rapat koordinasi Majelis Pengawas yang dihadiri Mahkamah Agung, Kejaksaan Agung dan Polri beranggapan bahwa akta yang dibuat dalam jumlah yang tidak wajar dianggap mempunyai/ada indikasi kuat merupakan pelanggaran jabatan dan dapat pula menjadi indikasi adanya pelanggaran pidana. Secara hakikat, seharusnya melalui akta autentik inilah diharapkan dapat dihindari terjadinya sengketa.

\footnotetext{
${ }^{1}$ Sjaifurrachman dan Habib Adjie, Aspek Pertanggungjawaban Notaris dalam Pembuatan Akta, Mandar Maju, Bandung, 2011, hlm. 121.
} 
Apabila terjadi suatu sengketa, akta autentik yang merupakan alat bukti tertulis terkuat dan terpenuh memberi sumbangan nyata bagi penyelesaian perkara yang menjadi sengketa tersebut. ${ }^{2}$ Hal yang tidak mungkin tercapai apabila dalam proses pembuatan akta otentik tersebut sudah mengandung unsur pelanggaran.

Untuk melindungi Jabatan Notaris dan mayarakat yang menggunakan jasa Notaris terkait kepastian hukum dari akta yang dibuat oleh Notaris, Dewan Kehormatan Pusat Ikatan Notaris Indonesia mengeluarkan Peraturan Dewan Kehormatan Pusat Nomor 1 Tahun 2017 Tentang Batas Kewajaran Jumlah Pembuatan Akta Perhari. Dalam (selanjutnya ditulis PDKP INI 1/2017), peraturan tersebut ditentukan oleh Dewan Kehormatan Pusat bahwa batas kewajaran dalam pembuatan akta per hari adalah sebanyak 20 (dua puluh) akta. Kehadiran peraturan ini menimbulkan pro dan kontra di kalangan khususnya di kalangan Notaris terkait kewenangan Dewan Kehormatan membatasi jumlah akta yang boleh dibuat oleh Notaris tersebut.

\section{B. RUMUSAN PERMASALAHAN}

Berdasarkan uraian tersebut diatas, maka penelitian ini didasarkan atas permasalahan sebagai berikut :

1. Apakah Dewan Kehormatan Pusat Ikatan Notaris Indonesia berwenang membatasi jumlah pembuatan akta oleh Notaris?

2. Apa Sanksi bagi Notaris yang melanggar ketentuan Peraturan DKP-INI No. 1 Tahun 2017

\section{METODE PENELITIAN}

Metode yang digunakan dalam penelitian ini adalah metode penelitian yuridis normatif yang menekankan pada norma-norma hukum dengan menganalisa peraturan perundangundangan terkait. Dalam Penelitian ini peneliti menggunakan dua metode pendekatan masalah yaitu 1) Statute Approach, pendekatan dengan menelaah semua peraturan perundangundangan yang bersangkut paut dengan permasalahan (isu hukum) yang sedang dihadapi. 2) Conseptual Approach, yaitu pendekatan yang beranjak dari pandangan-pandangan dan doktrin-doktrin yang berkembang di dalam ilmu hukum. ${ }^{3}$

\section{PEMBAHASAN}

\section{Sumber Kewenangan Dewan Kehormatan Pusat}

Notaris mempunyai kedudukan dan peran yang sangat penting dalam kehidupan berbangsa dan bernegara, karena mempunyai kewenangan atau authority yang telah ditentukan dalam peraturan perundang-undangan. Kewenangan notaris, yang dalam bahasa Inggrisnya disebut dengan the notary of authority, sedangkan dalam bahasa Belanda disebut dengan de notaris autoriteit, yaitu berkaitan dengan kekuasaan yang melekat pada diri seorang notaris. Ada dua

\footnotetext{
${ }^{2}$ Ibnu Sajadi, "Tanggung Jawab Notaris Terhadap Keabsahan Akta Notaris Yang Dibuatnya Atas Penghadap Yang Tidak Dapat Membaca Dan Menulis”, Jurnal Repertorium, Volume II No. 2 Juli - Desember 2015, hlm. 2 ${ }^{3}$ Peter Mahmud Marzuki, Penelitian Hukum, Kencana Prenada Media, Jakarta, 2010, hlm. 95-97
} 
suku kata yang terkandung dalam kewenangan notaris, yang meliputi: (1) kewenangan; dan (2) notaris. ${ }^{4}$

Ada dua unsur yang terkandung dalam konsep kewenangan yang disajikan oleh H.D. Stoud, yaitu: (1) adanya aturan-aturan hukum; dan (2) sifat hubungan hukum. Sebelum kewenangan itu dilimpahkan kepada institusi yang melaksanakannya, maka terlebih dahulu harus ditentukan dalam peraturan perundang-undangan, apakah dalam bentuk undang-undang, peraturan pemerintah maupun aturan yang lebih rendah tingkatannya. ${ }^{5}$ Sifat hubungan hukum adalah sifat yang berkaitan dan mempunyai sangkut paut atau ikatan atau pertalian atau berkaitan dengan hukum. Hubungan hukumnya ada yang bersifat publik dan privat. Sementara itu, notaris dikonstruksikan sebagai pejabat umum. Pejabat merupakan orang yang melakukan pekerjaan atau tugas untuk melayani kepentingan masyarakat secara keseluruhan. ${ }^{6}$

Dari uraian di atas, dapat disajikan pengertian kewenangan notaris. Kewenangan notaris dikonstruksikan sebagai: "Kekuasaan yang diberikan oleh undang-undang kepada notaris untuk membuat akta autentik maupun kekuasaan lainnya". Unsur-unsur yang terkandung dalam konsep kewenangan notaris, yang meliputi: (1) adanya kekuasaan; (2) ditentukan oleh undang-undang; dan (3) adanya objek. ${ }^{7}$

Kekuasaan diartikan sebagai kemampuan dari notaris untuk melaksanakan jabatannya. Kewenangan notaris dibagi menjadi dua macam, yaitu: (1) kewenangan membuat akta autentik; dan (2) kewenangan lainnya. Kewenangan lainnya merupakan kekuasaan yang telah ditentukan dalam peraturan perundang-undangan sebagaimana disbeutkan dalam Pasal 15 UUJN.

Notaris dalam menjalankan kewenangannya diawasi secara eksternal oleh Majelis Pengawas Notaris dan diawasi secara internal oleh Dewan Kehormatan Notaris. ${ }^{8}$ Pengawasan internal yang dimaksud dalam hal ini adalah pengawasan dalam lingkup organisasi Ikatan Notaris Indonesia yang secara garis besar ditekankan kepada pengawasan terhadap etika Notaris melalui Kode Etik yang telah ditetapkan oleh Ikatan Notaris Indonesia. Berbeda dengan kedudukan Majelis Pengawas Notaris yang secara eksplisit telah disebutkan dalam UUJN, kedudukan Dewan Kehormatan Notaris tidak disebutkan secara tegas dalam UUJN sehingga untuk memahami kedudukan serta sumber kewenangan Dewan Kehormatan Notaris terlebih dahulu harus dikonstruksikan melalui Pasal 82 dan Pasal 83 UUJN. ${ }^{9}$ Pada Pasal 82 UUJN disebutkan bahwa :

a. Notaris berhimpun dalam satu wadah Organisasi Notaris.

b. Wadah Organisasi Notaris sebagaimana dimaksud pada ayat (1) adalah Ikatan Notaris Indonesia.

\footnotetext{
${ }^{4}$ Salim H.S., Teknik Pembuatan Akta Satu (Konsep Teoritis, Kewenangan Notaris, Bentuk dan Minuta Akta), RajaGrafindo Persada, Jakarta, 2015, hlm. 47.

${ }^{5}$ H.D Stoud dalam Salim H.S., Ibid., hlm. 48.

${ }^{6}$ Putu Mas Maya Ramanti, "Tanggung Jawab Notaris Dalam Pembuatan Minuta Yang Dibuat Berdasarkan Keterangan Palsu”, Jurnal Acta Comitas, Prodi Magister Kenotariatan Universitas Udayana, Vol 1. 2016, hlm 108-118

${ }^{7}$ Salim H.S., Op. Cit., hlm. 49.

${ }^{8}$ Habib Adjie, Majelis Pengawas Notaris Sebagai Pejabat Tata Usaha Negara, Refika Aditama, Bandung, 2011, hlm. 26

${ }^{9}$ Ruslan, "Peranan Dan Fungsi Majelis Pengawas Wilayah Terhadap Pelaksanaan Tugas Jabatan Notaris", Jurnal Ilmu Hukum Legal Opinion, Edisi 5, Volume 1, Tahun 2013, hlm. 3
} 
c. Organisasi Notaris sebagaimana dimaksud pada ayat (1) merupakan satu-satunya wadah profesi Notaris yang bebas dan mandiri yang dibentuk dengan maksud dan tujuan untuk meningkatkan kualitas profesi Notaris.

d. Ketentuan mengenai tujuan, tugas, wewenang, tata kerja, dan susunan organisasi ditetapkan dalam Anggaran Dasar dan Anggaran Rumah Tangga Organisasi Notaris.

e. Ketentuan mengenai penetapan, pembinaan, dan pengawasan Organisasi Notaris diatur dengan Peraturan Menteri.

Dari ketentuan dalam Pasal 82 UUJN tersebut dapat dilihat bahwa Notaris berhimpun dalam satu wadah tunggal organisasi yaitu Ikatan Notaris Indonesia. Organisasi Notaris tersebut merupakan organisasi yang bebas dan mandiri yang dibentuk dengan maksud dan tujuan untuk meningkatkan kualitas profesi Notaris.

Pada Pasal 1 angka 5 UUJN ditegaskan pula bahwa yang dimaksud dengan Organisasi Profesi Notaris adalah merupakan organisasi yang berbadan hukum. Sebagai organisasi yang berbadan hukum maka Ikatan Notaris Indonesia memiliki Anggaran Dasar dan Anggaran Rumah Tangga sebagai konstitusi organisasi yang menentukan bagaimana jalannya organisasi Ikatan Notaris Indonesia. Hal tersebut sesuai dengan yang telah dinyatakan dalam Pasal 82 ayat (3) UUJN diatas, dalam Anggaran Dasar dan Anggaran Rumah Tangga Ikatan Notaris Indonesia diatur mengenai tujuan, tugas, wewenang, tata kerja, dan susunan organisasi.

Notaris sebagai Jabatan yang menjalankan profesi hukum tentunya diharapkan mampu memiliki keseragaman dalam cara bekerja secara profesional dan budi pekerti yang luhur. Hal tersebut dapat terwujud dengan adanya suatu standart perilaku bagi Notaris baik dalam menjalankan tugas jabatan maupun dalam menjalani kehidupan sehari-hari. Dari kondisi tersebut perlu ditetapkan suatu Kode Etik dalam organisasi Ikatan Notaris Indonesia.

Kode etik merupakan bagian yang tidak dapat dipidahkan dari organisasi profesi dan hampir semua organisasi profesi memiliki kode etiknya sendiri. Pada Ikatan Notaris Indonesia, kode etik yang diberlakukan memiliki karakter yang berbeda dengan kode etik organisasi profesi lainnya karena kode etik Ikatan Notaris Indonesia secara tegas disebutkan dalam UUJN. Ketentuan tersebut dapat dilihat dalam Pasal 83 UUJN yang menyatakan : “(1) Organisasi Notaris menetapkan dan menegakkan Kode Etik Notaris. (2) Organisasi Notaris memiliki buku daftar anggota dan salinannya disampaikan kepada Menteri dan Majelis Pengawas."

Ketentuan dalam Pasal 83 ayat (1) UUJN tersebut diatas memerintahkan organisasi Notaris, yaitu Ikatan Notaris Indonesia untuk menetapkan dan menegakkan kode etik. Secara historis, sebelum kode etik diperintahkan secara tegas dalam UUJN, Ikatan Notaris Indonesia telah memiliki kode etik yang pertama kali diputuskan dalam Kongres Ikatan Notaris Indonesia di Surabaya pada tahun $1974 .{ }^{10}$ Kode Etik Ikatan Notaris Indonesia tersebut dalam

${ }^{10}$ Pengurus Pusat Ikatan Notaris Indonesia, 100 Tahun Ikatan Notaris Indonesia : Jati Diri Notaris Indonesia Dulu, Sekarang Dan Di Masa Datang, Gramedia Pustaka, Jakarta, 2008, hlm. 198 
perjalanannya telah mengalami beberapa kali perubahan dan yang terkahir diputuskan dalam Kongres Luar Biasa Ikatan Notaris Indonesia di Banten pada tanggal 29-30 Mei 2015.

Pasal 83 ayat (1) UUJN tersebut diatas tidak hanya memerintahkan organisasi Ikatan Notaris Indonesia untuk menetapkan Kode Etik tetapi juga untuk menegakkan Kode Etik tersebut. Dari adanya perintah Undang-Undang tersebut Ikatan Notaris Indonesia kemudian membentuk Dewan Kehormatan untuk menegakkan Kode Etik Ikatan Notaris Indonesia. Perintah UUJN kepada organisasi Notaris untuk menegakkan Kode Etik tersebut selanjutnya ditindaklanjuti melaui Anggaran Dasar Ikatan Notaris Indonesia. Anggaran Dasar dalam Organisasi Ikatan Notaris Indonesia inipun sebelumnya juga telah disebutkan dalam Pasal 82 ayat (4) UUJN.

Pada Pasal 12 ayat (1) Anggaran Dasar Ikatan Notaris Indonesia disebutkan bahwa : "Dewan Kehormatan mewakili perkumpulan dalam hal pembinaan, pengawasan dan pemberian sanksi dalam penegakan Kode Etik". Kedudukan Dewan Kehormatan selanjutnya juga dinyatakan dalam Pasal 1 angka 8 Kode Etik Ikatan Notaris Indonesia yang menyatakan :

"Dewan Kehormatan adalah alat perlengkapan Perkumpulan yang dibentuk dan berfungsi menegakkan Kode Etik, harkat dan martabat Notaris, yang bersifat mandiri dan bebas dar keberpihakan, dalam menjalankan tugas dan kewenangannya dalam Perkumpulan. Dewan Kehormatan terdiri atas:

a. Dewan Kehormatan Pusat pada tingkat Nasional;

b. Dewan Kehormatan Wilayah pada tingkat Propinsi;

c. Dewan Kehormatan Daerah pada tingkat Kabupaten/Kota."

Dari uraian yang telah disebutkan diatas dapat disimpulkan bahwa sumber kewenangan Dewan Kehormatan Ikatan Notaris Indonesia adalah diperoleh melalui delegasi dari UUJN untuk menegakkan kode etik sebagaimana diperintahkan dalam Pasal 83 ayat (1) UUJN. Mengenai kewenangan Dewan Kehormatan Notaris disebutkan pada Anggaran Dasar, Anggaran Rumah Tangga dan Kode Etik Ikatan Notaris Indonesia. Pada Pasal 12 Anggaran Dasar Ikatan Notaris Indonesia hasil Kongres Luar Biasa Luar Biasa Ikatan Notaris Indonesia Banten, 29-30 Mei 2015 disebutkan :

"Dewan Kehormatan mempunyai tugas dan kewenangan untuk:

- melakukan bimbingan, pengawasan, pembinaan anggota dalam penegakan dan menjunjung tinggi Kode Etik Notaris;

- memeriksa dan mengambil keputusan atas dugaan pelanggaran ketentuan Kode Etik Notaris;

- memberikan saran dan pendapat kepada Majelis Pengawas dan/atau Majelis Kehormatan Notaris atas dugaan pelanggaran Kode Etik Notaris dan jabatan Notaris; 
- melakukan koordinasi, komunikasi, dan berhubungan secara langsung kepada anggota maupun pihak-pihak yang berhubungan dengan pelaksanaan dan penegakan Kode Etik Notaris;

- Membuat peraturan dalam rangka penegakan Kode Etik Notaris bersama-sama dengan Pengurus Pusat."

Kewenangan Dewan Kehormatan Notaris disebutkan pula dalam Pasal 6 ayat (3) Kode Etik Ikatan Notaris Indonesia yang menyatakan : "Dewan Kehormatan Pusat berwenang untuk memutuskan dan menjatuhkan sanksi terhadap pelanggaran yang dilakukan oleh anggota biasa (dari Notaris aktif) Perkumpulan, terhadap norma susila atau perilaku yang merendahkan harkat dan martabat Notaris atau perbuatan yang dapat mengurangi kepercayaan masyarakat terhadap Notaris."

\section{Kedudukan Dewan Kehormatan Pusat Ikatan Notaris Indonesia dalam Sistem Jabatan Notaris}

Notaris sebagai pejabat umum menjalankan suatu fungsi sosial yang sangat penting, yang meliputi kehidupan masyarakat pada umumnya, yang mana masyarakat meminta nasehatnasehat dari Notaris mengenai isi dari akta-akta yang dibuat oleh Notaris. Notaris juga memberikan nasehat-nasehat dan petunjuk-petunjuk sebagaimana dimaksud dari para pihak yang bersangkutan, dengan mengindahkan peraturan-peraturan dalam perundang-undangan yang berlaku sehingga dapat diwujudkan dengan sebaik-baiknya dan sedapat mungkin menghindarkan terjadinya perselisihan- perselisihan.

Dalam menjalankan tugas dari jabatannya Notaris mempunyai tugas untuk membuat akta otentik bagi masyarakat yang membutuhkan, akta otentik yang dibuat oleh Notaris adalah merupakan suatu pembuktian yang sempurna yang melahirkan suatu kepastian hukum apabila sewaktu-waktu terjadi perselisihan diantara para pihak yang membuat atau membutuhkan akta tersebut.

Sebagaimana layaknya seorang manusia yang tidak luput dari kesalahan dan keihlafan, maka Notaris juga adalah manusia sehingga Notaris juga bisa saja berbuat kesalahan dalam menjalankan tugas dan jabatannya sebagai seorang pejabat umum. Oleh karena tugasnya dan jabatannya sebagai pejabat umum yang berwenang, untuk membuat akta otentik, dan demi kepentingan masyarakat banyak maka untuk menghindari penyalahgunaan atau penyimpangan tugas dan jabatannya maka bagi Notaris dibentuk suatu Pengawas yang bertugas untuk mengawasi segala pekerjaan yang dilakukan oleh Notaris terutama dalam pembuatan akta agar tidak bertentangan dengan peraturan perundang-undangan yang berlaku.

Mekanisme pengawasan yang dilakukan terhadap pelaksanaan tugas dan jabatan Notaris adalah bersifat preventif maupun represif. Pengawasan yang dilakukan secara preventif adalah pengawasan yang dilakukan sebelum pelaksanaan, yang berarti pengawasan terhadap segala sesuatu yang masih bersifat rencana sedangkan pengawasan yang dilakukan secara represif adalah pengawasan yang dilakukan setelah pekerjaan atau kegiatan dilaksanakan.

Dewan kehormataan merupakan salah satu alat perlengkapan organisasi Ikatan Notaris Indonesia (INI) dan terdiri dari 3 (tiga) tingkat, yaitu tingkat pusat, wilayah, dan daerah. Keberadaan lembaga Dewan kehormatan diatur dalam Anggaran Dasar INI. 
Tugas Dewan Kehormatan sebagai berikut: ${ }^{11}$ Tugas utama Dewan Kehormatan adalah melakukan pengawasan terhadap pelaksanaan Kode Etik Notaris yang telah ditentukan oleh organisasi yang meliputi kewajiban, larangan, dan pengecualian yang harus dilakukan oleh para anggota organisasi. Dewan Kehormatan dalam melaksanakan tugasnya tersebut dapat melakukan pemeriksaan terhadap anggota organisasi yang diduga melakukan pelanggaran atas kode etik. Terhadap anggotanya yang bersalah, maka Dewan kehormatan berhak menjatuhkan sanksi sebagaimana tercantum pada Pasal 6 Kode Etik Notaris, yaitu:

A. Sanksi yang dikenakan terhadap anggota yang melakukan pelanggaran Kode Etik dapat berupa:
1) Teguran;
2) Peringatan;
3) Schorsing (pemecatan sementara) dari keanggotaan Perkumpulan;
4) Onzetting (pemecatan) dari keanggotaan Perkumpulan;
5) Pemberhentian dengan tidak hormat dari keanggotaan Perkumpulan.

B. Penjatuhan sanksi-sanksi sebagaimana terurai di atas terhadap anggota yang melanggar Kode Etik disesuaikan dengan kwantitas dan kwalitas pelanggaran yang dilakukan anggota tersebut.

Wewenang Dewan Kehormatan tersebut adalah terhadap pelanggaran kode etik organisasi yang dampaknya tidak berkaitan dengan masyarakat secara langsung atau tidak ada orangorang yang dirugikan dengan pelanggaran kode etik yang dilakukan oleh anggota organisasi, atau dengan kata lain wewenang Dewan Kehormatan bersifat internal organisasi. ${ }^{12}$ Berdasarkan Pasal 12 ayat (3) Keputusan Menteri Hukum dan Hak Asasi Manusia Republik Indonesia Nomor : C-18.HT.01.06 Tahun 2006 tentang Perubahan AD-ART INI dijelaskan bahwa Dewan Kehormatan berwenang melakukan pemeriksaan atas pelanggaran terhadap kode etik dan menjatuhkan sanksi kepada pelanggarnya sesuai dengan kewenangannya dan bertugas untuk:

a. Melakukan pembinaan, bimbingan, pengawasan, pembenahan anggota dalam menjunjung tinggi kode etik;

b. Memeriksa dan mengambil keputusan atas dugaan pelanggaran ketentuan kode etik yang bersifat internal atau yang tidak mempunyai hubungan dengan masyarakat secara langsung;

c. Memberikan saran dan pendapat kepada Majelis Pengawas atas dugaan pelanggaran kode etik dan jabatan notaris.

\footnotetext{
${ }^{11}$ Kelik Pramudya dan Ananto Widiatmoko, Pedoman Etika Profesi Aparat Hukum, Pustaka Yustisia, Yogyakarta, 2010, hlm. 81.

${ }^{12}$ Ibid., hlm. 82.
} 
Kedudukan Dewan Kehormatan Pusat dalam sistem profesi Jabatan Notaris di Indonesia adalah sebagai lembaga pada tingkatan yang paling tinggi dalam melakukan penegakan terhadap Kode Etik Ikatan Notaris Indonesia. Pasal 13 Kode Etik Ikatan Notaris Indonesia disebutkan bahwa Dewan Kehormatan melakukan upaya-upaya untuk menegakkan Kode Etik Notaris.Dalam penegakan Kode Etik tersebut Dewan Kehormatan diberi kewenangan bersama-sama dengan Pengurus Pusat untuk membuat peraturan dalam rangka penegakan Kode Etik. Atas kewenangan yang disebutkan dalam Pasal 12 Anggaran Dasar Ikatan Notaris Indonesia tersebut Dewan Kehormatan Pusat mengeluarkan Peraturan Dewan Kehormatan Pusat Nomor Tahun 2017 tentang Batas Jumlah Kewajaran Pembuatan Akta Perhari.

Dari uraian di atas, maka keberadaan Dewan Kehormatan dalam organisasi INI merupakan bentuk pengawasan secara internal kepada Notaris (anggotanya) agar dalam melaksanakan profesinya, notaris tidak melanggar kode etik, sedangkan secara eksternal pengawasan terhadap notaris dilakukan oleh pemerintah dalam hal ini Menteri Hukum dan HAM dengan mendelegasikan kewenangannya kepada Majelis Pengawas Notaris.

\section{Kekuatan Mengikat Peraturan Dewan Kehormatan Pusat Ikatan Notaris Indonesia Bagi Notaris}

Dalam setiap organisasi terutama dalam organisasi pemerintahan fungsi pengawasan adalah sangat penting, karena pengawasan adalah suatu usaha untuk menjamin adanya kearsipan antara penyelenggara tugas pemerintahan oleh daerah-daerah dan oleh pemerintah dan untuk menjamin kelancaran penyelenggaraan pemerintahan secara berdaya guna dan berhasil guna. $^{13}$

Pengawasan adalah salah satu fungsi dasar manajemen yang dalam bahasa Inggris disebut "controlling”. Dalam bahasa Indonesia, fungsi controlling itu mempunyai 2 (dua) padanan, yaitu pengawasan dan pengendalian. Pengawasan dalam hal ini adalah pengawasan dalam arti sempit, yaitu Segala usaha atau kegiatan untuk mengetahui dan menilai kenyataan yang sebenarnya tentang pelaksanaan tugas atau pekerjaan, apakah sesuai dengan yang semestinya atau tidak, sedangkan pengendalian pengertiannya lebih forceful daripada pengawasan, yaitu sebagai segala usaha atau kegiatan untuk menjamin dan mengarahkan agar pelaksanaan tugas atau pekerjaan berjalan sesuai dengan yang semestinya. ${ }^{14}$

Pengertian dasar dari pengawasan adalah segala usaha atau kegiatan untuk mengetahui dan menilai kenyataan yang sebenarnya tentang pelaksanaan tugas atau kegiatan, apakah sesuai dengan yang semestinya atau tidak. ${ }^{15}$ Pengawasan adalah proses pengamatan daripada pelaksanaan seluruh kegiatan organisasi untuk menjamin agar supaya semua pekerjaan yang sedang dilaksanakan berjalan sesuai dengan rencana yang telah ditentukan sebelumnya. ${ }^{16}$

\footnotetext{
${ }^{13}$ Viktor M. Situmorang dan Cormentyna Sitanggang, Hukum Administrasi Pemerintahan Di Daerah, Sinar Grafika, Jakarta, 1993, hlm. 233

${ }^{14}$ Sujamto, Aspek-aspek Pengawasan Di Indonesia, Sinar Grafika, Jakarta, 1987, h. 53

${ }^{15}$ Ibid, hlm. 63

${ }^{16}$ Sujamto, Beberapa Pengertian di Bidang Pengawasan, Yudhistira Ghalia Indonesia, Jakarta, 1983, hlm. 12
} 
Pengawasan terhadap pelanggaran Kode Etik Jabatan Notaris dilaksanakan oleh Dewan Kehormatan Notaris, bahwa kewibawaan institusi Notaris dapat tercermin dari suatu Dewan Kehormatan Notaris yang dapat merakukan tindakan dan menjatuhkan sanksi kepada Notaris yang melakukan pelanggaran Kode Etik Jabatan Notaris. ${ }^{17}$ Penegakan terhadap Kode Etik Ikatan Notaris Indonesia sebagaimana disebutkan dalam Pasal 83 ayat (1) UUJN dilakukan oleh Organisasi Notaris. Atas dasar ketentuan tersebut Organisasi Notaris yaitu Ikatan Notaris Indonesia melakukan penegakan Kode Etik melalui Dewan Kehormatan Pusat. Berdasarkan Anggaran Dasar Ikatan Notaris Indonesia disebutkan bahwa Dewan Kehormatan merupakan alat perlengkapan Perkumpulan yang bertugas untuk menegakkan Kode Etik.

Sebagai upaya dalam penegakan Kode Etik, Dewan Kehormatan Pusat bersama Pengurus Pusat Ikatan Notaris Indonesia berwenang untuk membuat Peraturan yang diwujudkan melalui PDKP INI. Peraturan tersebut merupakan penjabaran atas aturan tentang penegakan kode etik yang belum tertuang dalam Kode Etik Ikatan Notaris Indonesia. Sebagai Peraturan yang berfungsi untuk menegakkan kode etik maka PDKP mengikat bagi semua orang yang menjalankan jabatan Notaris. Hal tersebut didasarkan pada ketentuan yang disebutkan dalam Pasal 3 ayat 11 Kode Etik Ikatan Notaris Indonesia yang menyatakan "Notaris maupun orang lain (selama yang bersangkutan menjalankan jabatan Notaris) wajib : Menghormati, mematuhi, melaksanakan Peraturan-peraturan dan Keputusan-Keputusan Perkumpulan.” Kewajiban untuk mematuhi Kode Etik juga didasarkan pada sumpah jabatan yang pernah diucapkan oleh Notaris sebelum melaksanakan tugas jabatannya. Sumpah jabatan tersebut diatur dalam ketentuan Pasal 4 UUJN .

Dari konstruksi tersebut dapat diketahui bahwa PDKP INI juga merupakan bagian dari Kode Etik Ikatan Notaris Indonesia sehingga memilki kekuatan mengikat bagi Notaris maupun orang lain yang sedang menjalankan tugas jabatan sebagai Notaris.

\section{Sanksi Bagi Notaris Yang Melanggar Peraturan Dewan Kehormatan Pusat}

Pada bagian sebelumnya telah dijelaskan maksud dan tujuan pembatasan pembuatan akta bagi Notaris sebanyak 20 (dua puluh) akta perhari sebagaimana disebutkan dalam Pasal 1 PDKP INI 1/2017 adalah untuk melindungi masyarakat pengguna jasa Notaris dan Notaris itu sendiri. Hampir semua penegak hukum berpendapat bahwa dalam pembuatan akta yang melebihi jumlah wajar terindikasi terjadi suatu pelanggaran terhadap UUJN di dalamnya. Pelanggaran yang dimaksud adalah berkaitan dengan aspek formal suatu akta otentik. Pada Pasal 1868 BW telah disebutkan bahwa salah satu syarat akta otentik adalah dibuat dalam bentuk yang telah ditentukan oleh Undang-Undang. Makna "bentuk yang ditentukan oleh Undang-Undang" tersebut tidak hanya terbatas pada bentuk secara fisik tetapi meliputi juga tata cara pembuatannya. Untuk sempurnanya suatu akta otentik, maka akta tersebut harus dibacakan dan ditandatangani oleh para penghadap, 2 (dua) orang saksi dan Notaris. ${ }^{18}$

\footnotetext{
${ }^{17}$ Habib Adjie, Hukum Notaris Indonesia : Tafsir Tematik Terdadap UU No. 30 Tahun 2004 Tentang Jabatan Notaris, Refika Aditama, Bandung, 2008, hlm. 172-174

${ }^{18}$ Habib Adjie, Penafsiran Tematik Hukum Notaris Indonesia : Berdasarkan Undang-Undang Nomor 2 Tahun 2014 Tentang Perubahan Atas Undang-Undang Nomor 30 Tahun 2004 Tentang Jabatan Notaris, Refika Aditama, Bandung, 2015, hlm. 17-19
} 
Mengenai pembacaan akta tersebut menjadi kewajiban bagi Notaris dan juga menjadi aspek formal dalam akta otentik. Hal ini dapat dilihat dari ketentuan Pasal 16 ayat (1) huruf m UUJN yang menyatakan : “(1) Dalam menjalankan jabatannya, Notaris wajib : ... m. membacakan Akta di hadapan penghadap dengan dihadiri oleh paling sedikit 2 (dua) orang saksi, atau 4 (empat) orang saksi khusus untuk pembuatan Akta wasiat di bawah tangan, dan ditandatangani pada saat itu juga oleh penghadap, saksi, dan Notaris". Ketentuan pembacaan akta oleh Notaris ini memang diberikan sedikit alternatif yaitu dalam Pasal 16 ayat (7) UUJN yang menyatakan : "Pembacaan Akta sebagaimana dimaksud pada ayat (1) huruf $m$ tidak wajib dilakukan, jika penghadap menghendaki agar Akta tidak dibacakan karena penghadap telah membaca sendiri, mengetahui, dan memahami isinya, dengan ketentuan bahwa hal tersebut dinyatakan dalam penutup Akta serta pada setiap halaman Minuta Akta diparaf oleh penghadap, saksi, dan Notaris." Namun hal tersebut dibatasi melalui ketentuan dalam Pasal 16 ayat (8) UUJN yang menyatakan : Ketentuan sebagaimana dimaksud pada ayat (7) dikecualikan terhadap pembacaan kepala Akta, komparasi, penjelasan pokok Akta secara singkat dan jelas, serta penutup Akta”, sehingga meskipun penghadap menghendaki untuk membaca sendiri aktanya, tetap menjadi kewajiban Notaris untuk membacakan kepala akta dan komparisi, menjelaskan secara singkat isi akta serta membacakan bagian penutup akta.

Ketentuan lain mengenai pembacaan akta disebutkan pula pada Pasal 38 ayat (4) huruf a UUJN bahwa "(4) Akhir atau penutup akta memuat : a. Uraian tentang pembacaan akta...". Terakhir ketentuan pembacaan akta disebutkan dalam Pasal 44 ayat (1) UUJN yang menyatakan : "Segera setelah akta dibacakan, Akta tersebut ditandatangani...". Ketentuan tersebut menegaskan bahwa pembacaan akta merupakan hal yang wajib dilakukan dalam pembuatan akta otentik dan apabila tidak dilaksanakan maka akta tersebut hanya mempunyai kekuatan pembuktian sebagai akta di bawah tangan saja sebagaimana telah ditegaskan dalam Pasal 16 ayat (9) jo. Pasal 41 jo. Pasal 44 ayat (5) UUJN. Uraian tentang kedudukan pembacaan akta tersebut diatas menunjukkan betapa pentingnya pembacaan akta dalam pembuatan akta oleh Notaris karena berkaitan dengan otensitas suatu akta. Hal inilah yang mendasari lahirnya PDKP INI 1/2017. Suatu akta yang dibuat melebihi jumlah wajar terindikasi mengesampingkan aspek formal tentang pembacaan akta. Pelanggaran yang sering terjadi adalah bahwa akta tersebut tidak dibacakan sehingga hanya mempunyai kekuatan pembuktian sebagai akta di bawah tangan.

Akta yang hanya mempunyai kekuatan pembuktian di bawah tangan tersebut tidak akan terlalu menjadi masalah jika yang termuat dalam akta hanya sebatas perjanjian yang disepakati oleh para pihak dan para pihak mengakui kebenaran semua perbuatan yang dilakukan dalam akta. Namun hal ini akan menjadi masalah jika akta yang dibuat merupakan syarat lahirnya suatu hubungan hukum yang telah ditentukan oleh Undang-Undang misalnya dalam suatu pendirian Perseroan Terbatas yang disyaratkan dibuat dengan akta otentik. Terdegradasi kedudukan akta menjadi akta dibawah tangan karena tidak dibacakan membuat akta pendirian PT tersebut menjadi tidak sah sebab aktanya hanya akta dibawah tangan dan bukan akta otentik.

Atas dasar itulah Dewan Kehormatan Ikatan Notaris Indonesia mengeluarkan PDKP INI 1/2017 sebagai solusi untuk mengendalikan perilaku Notaris dalam menjalankan tugas jabatan 
sehingga mampu memberikan kepastian hukum dalam produk yang dibuatnya. Melalui peraturan ini Notaris diharapkan mampu menghindari larangan yang telah disebutkan dalam Pasal 4 angka 16 Kode Etik Ikatan Notaris Indonesia bahwa Notaris atau semua orang yang menjalankan jabatan Notaris dilarang membuat akta melebihi batas kewajaran. Peraturan ini sekaligus dibuat untuk menegakkan larangan dalam Kode Etik tersebut. Sebagaimana telah diuraikan sebelumnya bahwa Kode Etik mengikat Notaris dan semua orang yang menjalankan Jabatan Notaris karena dalam sumpah jabatan yang diucapkan oleh Notaris sebelum menjalankan tugas jabatannya Notaris bersumpah untuk menjalankan kewajiban sesuai dengan Kode Etik Profesi. PDKP INI 1/2017 merupakan bagian tidak terpisahkan dari Kode Etik INI sehingga apabila Notaris melanggar ketentuan PDKP INI 1/2017 maka sama dengan Notaris melanggar Kode Etik INI dan atas pelanggaran tersebut Notaris dapat dikenakan sanksi.

Sanksi bagi Notaris yang melanggar PDKP INI 1/2017 tersebut dapat berupa sanksi internal dan sanksi eksternal. Sanksi internal yang dimaksud adalah sanksi organisatoris yang dijatuhkan oleh Dewan Kehormatan berupa Teguran; Peringatan; Schorsing (pemecatan sementara) dari keanggotaan Perkumpulan; Onzetting (pemecatan) dari keanggotaan Perkumpulan; Pemberhentian dengan tidak hormat dari keanggotaan Perkumpulan. Sedangkan sanksi eskternal bagi Notaris yang melanggar PDKP INI 1/2017 adalah berupa pemberhentian sementara. Hal ini diatur dalam Pasal 9 ayat (1) huruf d UUJN yang menyatakan : “(1) Notaris diberhentikan sementara dari jabatannya karena : ... d. melakukan pelanggaran terhadap kewajiban dan larangan jabatan serta kode etik Notaris;...”.

Uraian tersebut diatas telah menjelaskan bagaimana kekuatan mengikat PDKP INI 1/2017 yang sifatnya tidak hanya internal organisasi saja tetapi sudah berada dalam lingkup Undang-Undang karena baik Organisasi Ikatan Notaris Indonesia, Kode Etik Ikatan Notaris Indonesia dan segala alat perlengkapan perkumpulan Ikatan Notaris Indonesia yang disebutkan dalam Anggaran Dasar Ikatan Notaris Indonesia adalah merupakan bagian yang tidak terpisahkan dari UUJN.

\section{E. PENUTUP}

\section{Kesimpulan}

Dewan Kehormatan Pusat berwenang membatasi jumlah pembuatan akta Notaris karena berdasarkan Anggaran Dasar Ikatan Notaris Indonesia telah disebutkan tugas dan kewenangan Dewan Kehormatan adalah untuk menegakkan Kode Etik. Dalam Kode Etik Ikatan Notaris Indonesia telah dinyatakan bahwa Notaris dan semua orang yang menjalankan Jabatan Notaris dilarang untuk membuat akta dalam jumlah diluar kewajaran. Pembuatan Akta dalam jumlah wajar tersebut selanjutnya ditindaklanjuti melalui Peraturan Dewan Kehormatan Pusat Ikatan Notaris Indonesi Nomor 1 Tahun 2017.

Notaris yang melanggar Peraturan Dewan Kehormatan Pusat Nomor 1 Tahun 2017 dapat dikenakan sanksi internal dan sanksi eksternal. Sanksi internal tersebut dapat berupa Teguran; Peringatan; Schorsing (pemecatan sementara) dari keanggotaan Perkumpulan; Onzetting (pemecatan) dari keanggotaan Perkumpulan; Pemberhentian dengan tidak hormat dari 
keanggotaan Perkumpulan. Sedangkan sanksi eskternal adalah berupa pemberhentian sementara dari Jabatan Notaris.

\section{Saran}

Notaris diharapkan mampu bekerja secara profesional agar mampu memberikan kepastian hukum bagi masyarakat yang menggunakan jasanya. Pemabatasan jumlah pembuatan akta Notaris oleh Peraturan Dewan Kehormatan bertujuan untuk melindungi masyarakat dan Notaris sendiri dari kemungkinan terjadinya permasalahan di kemudian hari sehingga sudah selayaknya Notaris mematuhi peraturan tersebut.

\section{DAFTAR PUSTAKA}

\section{Buku}

Habib Adjie, Hukum Notaris Indonesia : Tafsir Tematik Terdadap UU No. 30 Tahun 2004 Tentang Jabatan Notaris, Refika Aditama, Bandung, 2008.

--------------, Majelis Pengawas Notaris Sebagai Pejabat Tata Usaha Negara, Refika Aditama, Bandung, 2011.

, Penafsiran Tematik Hukum Notaris Indonesia : Berdasarkan Undang-Undang Nomor 2 Tahun 2014 Tentang Perubahan Atas Undang-Undang Nomor 30 Tahun 2004 Tentang Jabatan Notaris, Refika Aditama, Bandung, 2015.

Kelik Pramudya dan Ananto Widiatmoko, Pedoman Etika Profesi Aparat Hukum, Pustaka Yustisia, Yogyakarta, 2010.

Pengurus Pusat Ikatan Notaris Indonesia, 100 Tahun Ikatan Notaris Indonesia : Jati Diri Notaris Indonesia Dulu, Sekarang Dan Di Masa Datang, Gramedia Pustaka, Jakarta, 2008.

Peter Mahmud Marzuki, Penelitian Hukum, Kencana Prenada Media, Jakarta, 2010.

Salim H.S., Teknik Pembuatan Akta Satu (Konsep Teoritis, Kewenangan Notaris, Bentuk dan Minuta Akta), RajaGrafindo Persada, Jakarta, 2015.

Sjaifurrachman dan Habib Adjie, Aspek Pertanggungjawaban Notaris dalam Pembuatan Akta, Mandar Maju, Bandung, 2011.

Sujamto, Aspek-aspek Pengawasan Di Indonesia, Sinar Grafika, Jakarta, 1987.

-, Beberapa Pengertian di Bidang Pengawasan, Yudhistira Ghalia Indonesia, Jakarta, 1983.

Viktor M. Situmorang dan Cormentyna Sitanggang, Hukum Administrasi Pemerintahan Di Daerah, Sinar Grafika, Jakarta, 1993.

\section{Jurnal}

Ibnu Sajadi, "Tanggung Jawab Notaris Terhadap Keabsahan Akta Notaris Yang Dibuatnya Atas Penghadap Yang Tidak Dapat Membaca Dan Menulis", Jurnal Repertorium, Volume II No. 2 Juli - Desember 2015. 
Putu Mas Maya Ramanti, “Tanggung Jawab Notaris Dalam Pembuatan Minuta Yang Dibuat Berdasarkan Keterangan Palsu", Jurnal Acta Comitas, Prodi Magister Kenotariatan Universitas Udayana, Vol 1. 2016.

Ruslan, "Peranan Dan Fungsi Majelis Pengawas Wilayah Terhadap Pelaksanaan Tugas Jabatan Notaris”, Jurnal Ilmu Hukum Legal Opinion, Edisi 5, Volume 1, Tahun 2013.

\section{Peraturan Perundang-Undangan}

Undang-Undang Republik Indonesia Nomor 2 Tahun 2014 Tentang Perubahan Atas UndangUndang Nomor 30 Tahun 2004 Tentang Jabatan Notaris (Lembaran Negara Republik Indonesia Tahun 2014 Nomor 3), Tambahan Lembaran Negara Republik Indonesia Nomor 5491

Undang-Undang Republik Indonesia Nomor 30 Tahun 2004 Tentang Jabatan Notaris (Lembaran Negara Republik Indonesia Tahun 2004 Nomor 117), Tambahan Lembaran Negara Republik Indonesia Nomor 4432 